This work is licensed under a Creative Commons Attribution 4.0 International License.

Ovaj rad dostupan je za upotrebu pod licencom Creative Commons Imenovanje 4.0 međunarodna.

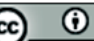

EIdi GRUBIŠIĆ PULIŠELIĆ

Filozofski fakultet Sveučilišta u Splitu, Hrvatska

Poljička cesta 35, 21 000, Split

eldi@ffst.hr
UDK 821.112.2(436).09 Hartwig, M.-32

DOI: https://doi.org/10.29162/ANAFORA.v8i2.7

Origineller wissenschaftlicher Beitrag

Original Research Article

Erhalten am 2.6. 2021

Received: 2 June 2021

Angenommen am 18. 8. 2021

Accepted: 18 August 2021

\title{
(PSIHO)PATOLOŠKI FENOMENI U EKSTAZAMA MELE HARTWIG
}

\section{Sažetak}

U fokusu rada nalaze se (psiho)patološki fenomeni koji povezuju ženske junakinje iz četiriju djela austrijske književnice Mele Hartwig. Poveznicu među glavnim junakinjama tvori njihov položaj spram društvenih vrijednosti, mjerila i očekivanja, odnosno njihova izopćenost. U novelama Zločin, Zapisi jedne ružne žene i Fantastični paragraf junakinje su primorane nositi se s različitim paradigmama mizogine austrijske kulture početkom 20. stoljeća. U noveli Vještica, smještenoj u 17. stoljeće, društvena konstelacija ponešto je drukčija, pa se junakinja suočava s modificiranim konceptima moći. Hartwig preispituje različite (psiho)patološke fenomene kod svojih ženskih likova i razotkriva (izvan)institucionalne mehanizme koji uspostavljaju ili brišu granicu između normalnog/prihvatljivog i bolesnog/neprihvatljivog ponašanja. Njezine junakinje na ugnjetavanje reagiraju pokušajem samoubojstva, promiskuitetnim ponašanjem, deluzijama, povlačenjem u paralelni svijet mašte, konstruiranjem natprirodnih doživljaja, pa čak i ubojstvom. Psihopatološki fenomeni koji postaju sastavni dio njihova identiteta i prate njihovo tjelesno i duševno izražavanje, projiciraju očajnički poziv u pomoć. Njihova borba završava porazom jer se kao samotne jedinke ne mogu oduprijeti snazi utjelovljenoj u institucional- 
nim autoritetima. Autorica u svojim tekstovima pokazuje tjeskobnu, depresivnu, pa i psihotičnu stvarnost žene; šokantne i/ili bizarne situacije koje literarizira čitateljima omogućuju rekonstrukciju atmosfere doba koje je, paradoksalno, u pisanim izvorima i kolektivnom sjećanju poznato kao zlatne dvadesete.

Ključne riječi: Mela Hartwig, psihopatološki fenomeni, mizoginija, institucionalna moć, žene

\section{Uvodno razmatranje}

Mela Hartwig rođena je 1893. u Beču kao Melanie Herzl u obitelji židovskog porijekla. Njezin otac, sociolog Theodor Herzl konvertirao je 1895. na katolicizam i promijenio obiteljsko prezime u Hartwig (Fraisl 140). Autorica u rodnom Beču završava Konzervatorij 1921. godine i dobiva glumačke angažmane u Beču, Olmützu i Berlinu. Između ostalih uloga, glumila je Ibsenovu Heddu Gabler, Hofmannstahlovu Elektru, Wedekindovu Lulu, Grillparzerovu Židovku iz Toleda i Wildeovu Salomé pa se može zaključiti da je problematične i psihopatološke ženske likove iz kazališnih predstava dalje razvijala u svojim novelama i romanima (Schmid-Bortenschlager 91). Prekretnicu u njezinu životu označava udaja za odvjetnika Roberta Spiru zbog koje se 1921. seli u Graz i prekida glumačku karijeru (Fraisl 139-147). Iako će do kraja života objavljivati pod djevojačkim prezimenom Hartwig, u različitim izvorima spominje se i kao Mela Spira. Književnost ju počinje zaokupljati još u doba glumačke karijere pa već od 1918. objavljuje pjesme u časopisima (Fraisl 141). Njezin ulazak u svijet književnosti započinje događajem kojim će privući pozornost književne javnosti: 1927. godine osvaja tada iznimno uglednu književnu nagradu. Natječaj časopisa Svijet književnosti (Die literarische Welt) na koji se javila imao je za cilj otkriti nove književne talente, a nagradu je osvojila s novelom Zločin (Das Verbrechen). O važnosti nagrade govori i podatak da je Alfred Döblin bio član žirija (Fast 69-70). Godinu dana nakon osvojene nagrade, 1928. godine, objavljuje zbirku novela pod naslovom Ekstaze (Ekstasen) koja sadrži i nagrađenu novelu. Knjigu je prvotno htjela nazvati Opsjednute (Besessene), ali je pod utjecajem izdavača promijenila naslov (Rinke 29). Ekstaze izlaze u nakladi od 5000 primjeraka kod bečkog izdavača Paul Zsolnay (Hall 177). Julius-Reich-Preis, nagradu koja se u Beču dodjeljivala mladim piscima i slikarima, osvaja 1929. godine (Fast 69). Nakon uspjeha Ekstaza kod istog izdavača 1929. izlazi autoričin prvi roman pod naslovom Žena je jedno ništa (Das Weib ist ein Nichts) (Hall 177). Moglo bi se reći da time zavr- 
šava sretno razdoblje njezine književne karijere jer za sljedeći roman više neće uspjeti naći izdavača (Fähnders 162-65). Promijenjeni ukus književne publike, ali prije svega nova kulturna politika koja nastaje kao posljedica političkih okolnosti, odjednom ju kao ženu židovskog porijekla čine nepodobnom autoricom. Za Hartwig nastupaju teška i nesigurna vremena u kojima se mora suočiti s posljedicama nacionalsocijalističke ideologije i dolaskom nacista na vlast. Rastući antisemitizam, zabrane, progoni i sustavno uništavanje kulture, pogotovo one povezane s autorima židovskog porijekla i protivnicima režima, za nju, kao i za mnoge druge pisce, znači nemogućnost daljnjeg objavljivanja. Svjesna toga da je odlazak u egzil jedina opcija koju ima, Mela Hartwig u pratnji svog supruga odlazi u Veliku Britaniju gdje preživljavaju baveći se poučavanjem i novinarstvom (Fraisl 146). Kao što je to nerijetko bio slučaj kod austrijskih i njemačkih pisaca koji su bili prisiljeni emigrirati, njezino ime nestaje iz književne javnosti. Iako će nakon rata pokušati uspostaviti davno prekinute književne veze s domovinom, u tome nažalost neće uspjeti. Kad joj dva desetljeća nakon završetka Drugog svjetskog rata, za njezin 70. rođendan, u Austriji posvete radijsku emisiju, ona zahvaljuje u pismu u kojemu priznaje koliko je nestanak iz književne javnosti za nju bio bolan (Fraisl 145). Zbog spomenutih okolnosti autorica ostaje živjeti u Londonu, europskoj metropoli koja pruža dovoljno prostora i mogućnosti za umjetničku afirmaciju, ali će gubitak čitalačke publike za nju predstavljati nenadoknadiv deficit. Nastavit će pisati u tišini svoje anonimnosti te za života više neće objavljivati (Fast 70). Vjerojatno se upravo zbog toga u kasnijim godinama više posvetila slikanju kao drugačijem mediju izražavanja. Umrla je 1967. godine pomalo razočarana neprihvaćanjem koje je doživjela u Austriji. Trebalo je proći još tri desetljeća prije nego što se ponovo probudio interes za autoricu i njezino književno stvaralaštvo. Negdje krajem 20. i početkom 21. stoljeća ponovo se tiskaju njezina već prije objavljena književna djela, između njih i novele prvi put objavljene pod naslovom Ekstaze, dok se neka druga njezina djela objavljuju prvi put (Grubišić Pulišelić, Witches 42).

U fokusu ovog istraživanja nalaze se (psiho)patološki fenomeni koji povezuju ženske junakinje iz četiri novele (Zločin; Vještica; Zapisi jedne ružne žene i Fantastični paragraf) sadržane u autoričinu književnom prvijencu, zbirci novela Ekstaze. Poveznicu među njima čini pozicioniranje glavnih junakinja u odnosu prema društvenim vrijednostima, mjerilima i očekivanjima, odnosno njihov autsajderski status zbog kojeg bivaju stigmatizirane, zlostavljane, izopćene, osuđene, zatočene ili čak ubijene. U novelama Zločin, Zapisi jedne ružne žene $i$ 
Fantastični paragrafjunakinje se moraju konfrontirati s različitim paradigmama mizogine austrijske kulture s početka 20. stoljeća. One postaju žrtve znanstvenih teorija, institucija, zakonodavstva, etičkih principa i svjetonazora koje su (za njih) kreirali muškarci. U Vještici je ta konstelacija drugačija, ali kao što će analiza pokazati, suštinski zapravo jednaka. $U$ toj noveli koja se događa u doba tridesetogodišnjeg rata, junakinja se suočava s nešto izmijenjenim konceptima vlasti i moći te postaje žrtva socijalne strukture i svjetonazora 17. stoljeća; rata, ideologije, inkvizicije, ali i praznovjerja, bolesti i gladi.

Na prijelazu iz 19. u 20. stoljeće pojavljuje se veliki broj tekstova u kojima se njihovi autori bave ženskom biti, prirodom, ulogom i položajem. Žensko tijelo pokušava se objasniti pomoću različitih teorija o njegovoj funkciji; nerijetko se promatra u kontekstu patologije pa se čak može zaključiti da se postavlja dijagnoza tzv. bolesti žena (Catani 19). Najpoznatijim teoretičarima u tom kontekstu pripadaju liječnik Sigmund Freud i filozof Otto Weininger (Catani 9-11). Weininger u studiji Spol i karakter (Geschlecht und Charakter) iz 1903. na temelju različitih izvora nastoji dokazati da je žena po svojoj prirodi inferiorna u odnosu na muškarca. Zahvaljujući tom djelu koje je na početku 20. stoljeća imalo veliki odjek i utjecaj, autora danas nazivaju jednim od najvećih teoretičara mizoginije (Wagner 169-84). Liječnik Sigmund Freud s druge strane u to doba utemeljuje psihoanalizu u okviru koje se seksualnost žene, ali i njezin cjeloviti identitet, promatraju u kontekstu anatomske razlike između spolova (Lohmann 30). Iako je pojam histerije postojao i prije njegovih istraživanja, upravo Freud dolazi do zaključka da histerija kod žena nastaje kao posljedica potisnute seksualnosti. Sam pojam iz znanstvenog diskursa ulazi u prostor javnog života te često služi kao osnova u tumačenju patološke prirode žene (Catani 23-33). S obzirom na činjenicu da su javnim prostorom u potpunosti vladali muškarci, ne iznenađuje da su upravo oni bili autori svih utjecajnih teorija o ženskoj prirodi i biti.

Mada se može ustvrditi da se proces emancipacije intenzivira nakon 1. Svjetskog rata, društvo koje Mela Hartwig problematizira u svojim novelama pod velikim je utjecajem konzervativnih vrijednosti i mizoginih teorija s kraja 19. i početka 20. stoljeća (Grubišić Pulišelić, Žena je jedno ništa 95-96). Čak i nakon velike političke pobjede, odnosno uvođenja biračkog i drugih građanskih prava 1918. godine, žene su u austrijskom društvu bile diskriminirane na svim razinama (Bader-Zaar 93-117). Upravo se zato muški protagonisti u analiziranim novelama Mele Hartwig pokazuju kao oni koji određuju pravila ponašanja, uspostavljaju granice između prihvatljivog i neprihvatljivog, između zdravog i 
patološkog, između lijepog i ružnog (Polt-Heinzl 211). Njihovo pravo nije samo deklarativno jer oni imaju stvarnu moć nad ženama, nagrađuju ih i kažnjavaju sukladno svojim potrebama i svjetonazoru te ih silom koja se temelji na zakonskim i etičkim normama zadržavaju u submisivnom položaju. Oni su liječnici, znanstvenici, vojni zapovjednici, crkveni autoriteti, suci i profesori, dok su žene niže pozicionirane na socijalnoj ljestvici i predstavljaju bolničarke, nahočad, siromašne studentice bez perspektive ili mlade žene bez konkretnog zanimanja. Patrijarhalna kultura koju su stoljećima izgrađivali omogućava muškim subjektima da sačuvaju svoju dominaciju i sprječava zamjenu uloga u poziciji moći. Ženski su likovi stoga prisiljeni na devijantne modele ponašanja i reagiraju (auto)destruktivnim utvrđivanjem vlastitog identiteta. Ono je zapravo odraz njihove borbe s fizičkom i psihičkom boli te se javlja kao reakcija na proživljeno traumatično iskustvo. Junakinje svoj bunt izražavaju pokušajem samoubojstva, promiskuitetnim ponašanjem, deluzijama, povlačenjem u paralelni svijet fantazija, konstruiranjem natprirodnih doživljaja pa čak i ubojstvom. Psihopatološki fenomeni koji postaju integralni dio njihova identiteta i prate njihovo tjelesno i duševno izražavanje, projiciraju njihov očajnički poziv u pomoć. Usamljenost, osjećaj napuštenosti, nepripadanja i nesnalaženja u realnosti pokazuju se kao ključna mjesta u konstrukciji njihova subjektiviteta. Junakinje psihopatološkim uzorcima ponašanja zapravo ugrožavaju patrijarhalnu, a time i političku strukturu moći pa za to uvijek plaćaju (pre)visoku cijenu. Njihova borba završava porazom jer kao usamljene jedinke ne mogu pobijediti snagu utjelovljenu $\mathrm{u}$ državnim i vjerskim institucijama/autoritetima, odnosno u znanosti, medicini, vojsci, crkvi i pravosuđu. Autorica u svojim književnim tekstovima pokazuje tjeskobnu, depresivnu pa i psihotičnu stvarnost žene (Rinke 34), šokantne i/ili bizarne situacije koje literarizira omogućavaju čitateljima rekonstrukciju atmosfere jednog doba koje je, paradoksalno, u pisane izvore i kolektivnu memoriju ušlo pod sintagmom zlatne dvadesete (Lickhardt 132).

\section{Zločin (Das Verbrechen)}

U fokusu novele Zločin nalazi se psihopatološki odnos između psihijatra dr. Zube i njegove kćeri Agnes koji završava repozicioniranjem njihovih uloga, odnosno zamjenom pozicije žrtve i zlostavljača. Naslov novele može se tumačiti dvostruko jer označava ocoubojstvo do kojeg dolazi na njezinu kraju, ali i psihoanalizu kojoj je mlada žena bila izložena i koja dovodi do njezina psihičkog i emocionalnog sloma. Zahvaljujući upravo takvom naslovu, naratološka i semantička ambivalencija postaju konstitutivni element cijele priče (Box 35). 
Otac, dr. Egon Zuba, začetnik je i nositelj psihopatološke igre u kojoj Agnes, njegova kći, postaje žrtva. On je psihijatar i sljedbenik Freudovih teorija pa djevojku podvrgava psihoanalizi i skrivajući se iza autoriteta znanosti, obiteljski dom pretvara u prostor represije. Zuba predstavlja dvostruku moć jer je autoritarni pater familias - samohrani roditelj koji u potpunosti dominira životom svog djeteta, ali i liječnik koji u vlastitoj obitelji provodi eksperiment. Psihoanaliza mu služi kao okvir unutar kojeg svojoj kćeri postavlja dijagnozu Elektrina kompleksa (Lohmann 17-18). Agnes, odrasla u sjeni njegova autoriteta, u početku je šokirana njegovom hipotezom, ali ju s vremenom prihvaća i time joj daje legitimitet (Grubišić Pulišelić, Žena je jedno ništa 98). Književna inscenacija Elektrina kompleksa ne može se smatrati pukom reprodukcijom psihoanalitičke teorije jer se u tekstu dekonstruiraju pretpostavke psihoanalize dok se na različitim naratološkim razinama kruži oko motiva ocoubojstva koji se nalazi u fokusu radnje (Box 24).

Junakinja je već na početku novele portretirana kao psihopatološki lik; ona danima leži u mraku svoje zaključane sobe i intenzivno razmišlja o samoubojstvu. Postupno se otkriva uzrok njezine depresije i pruža objašnjenje za tjeskobnu atmosferu u kojoj živi. Zaštićen autoritetom psihijatra, njezin ju otac naziva svojom „najtežom pacijenticom“ i time zadržava u poziciji objekta/žrtve svog eksperimenta. Svoju manipulaciju naziva „igrom“ koju zasniva na stalnoj izmjeni raspoloženja, odnosno (re)definiranju njihova odnosa (Box 27). Dr. Zuba konstantno mijenja obrazac ponašanja i diskurs kojim se služi na relaciji otac - kći pa u određenom trenutku demonstrira roditeljsku brigu i ljubav, da bi potom promijenio svoje ponašanje u optuživanje, ponižavanje, distanciranje i odbijanje (Box 27). Agnes je djevojka u dobi u kojoj se počinje formirati u odraslu osobu: ona izvan toksične atmosfere vlastita doma živi uobičajenim životom tzv. nove žene (Fraisl 154). Usprkos tome što u javnosti pokazuje samosvijest tipičnu za građansku djevojku zlatnih dvadesetih, Agnes se ne uspijeva othrvati ulozi žrtve u očevu eksperimentu/zlostavljanju. To ne znači da ona nije svjesna svoje pozicije u procesu psihoanalize kojoj je podvrgnuta: junakinja objašnjava da samu sebe percipira kao tijelo koje leži „na stolu za seciranje“, dok njezin otac/psihijatar „krvavim rukama kopa po njezinoj utrobi“ (Hartwig, Das Verbrechen 23) ${ }^{1}$. Zuba svoju kćer u potpunosti tretira kao objekt medicinskog eksperimenta pa joj uz Elektrin kompleks dijagnosticira i tzv. histeriju, pojam koji se može smatrati polazišnom točkom psihoanalize (Matijašević 1). On stalno

${ }^{1}$ Sve prijevode citata iz novela potpisuje autorica članka. 
mijenja perspektivu iz koje analizira psihu svoje kćeri, ali i svoj identitet iz kojeg nastupa pa se u jednom trenutku postavlja kao otac koji želi zaštititi svoje dijete, a potom kao muškarac koji ju promatra kao seksualni objekt: „Ja sam iskreniji od tebe, rekao bih i priznajem tebi i sebi bez konvencionalnog stida, da bih $\mathrm{u}$ svako doba bio spreman biti tvoj ljubavnik da na nesreću nisam tvoj otac" (Hartwig, Das Verbrechen 23). Agnes razvija osjećaj bezvrijednosti pa čak i zdravi odnos s ocem u djetinjstvu vidi u incestuoznom kontekstu. Zuba joj na taj način oduzima ne samo sadašnjost i budućnost, već i prošlost: „Njezino se djetinjstvo raspalo u gađenju tog trenutka" (Hartwig, Das Verbrechen 25). Radnja se uglavnom odvija kronološki, ali je prekinuta analepsama koje daju nova značenja i tumačenja, pogotovo u kontekstu Agnesina prihvaćanja krivnje, ali i razvoja lika njezina oca (Box 24). Iako je jasno da je ona žrtva njegova sadizma, Zuba ju u svojoj manipulativnoj igri uvjerava u to da joj zapravo želi pomoći: „Ti nemaš pravo na to, jedan primitivni erotski konflikt kojemu podliježu svi ljudi, podići na osobno pitanje biti ili ne biti. [...] Ja sam ti povjerio tajnu o tvom duševnom oboljenju, da bih ti pomogao [...]“" (Hartwig, Das Verbrechen 27). Kad Agnes zaprijeti da će se osloboditi njegova toksičnog utjecaja i pobjeći u nepoznato, čime pokušava preuzeti kontrolu nad svojim životom, on ju ucjenjuje da će se u tom slučaju ponovo oženiti. To je jedna od situacija u kojima junakinja demonstrira psihopatologiju koja se kod nje razvila kao posljedica igre: ona ostaje uz svog zlostavljača jer se više boji gubitka bliskosti s njim nego vlastite smrti. Može se zaključiti da Agnes nije u stanju adekvatno odgovoriti na potencijalni gubitak očeve ljubavi jer je sva moć koncentrirana upravo u njegovim rukama. Čak i kad mu prijeti da će policiji prijaviti seksualno zlostavljanje, on superiorno zaključuje: „Provjerit će se tvoje djevičanstvo i naći ga netaknutog. I onda ću te morati zatvoriti u umobolnicu“" (Hartwig, Das Verbrechen 34). Hartwig pokazuje da je muškarac taj koji ženi postavlja dijagnozu psihopatološkog poremećaja i predstavlja autoritet koji određuje njezinu sudbinu: život, smrt ili zatvaranje u umobolnicu. Svoju apsolutnu vlast nad njezinim/ženskim tijelom Zuba/muškarac demonstrira u sceni u kojoj ju brutalno pretuče, a ona mu klečeći ljubi ruke i moli ga za oprost. Agnes nakon tog nasilnog čina intenzivno pokušava isprovocirati seksualni odnos s ocem jer ima potrebu dokazati mu svoje kajanje i ljubav. Uhodi ga, moli da ju poljubi i jedne noći u njegovoj sobi gola pleše pred njim: „Imaj suosjećanja sa mnom. Ja ću izgorjeti. Uzmi moje tijelo iz sažaljenja, iz sažaljenja. Ja te molim“ (Hartwig, Das Verbrechen 52). Zuba se postavlja superiorno i odbija ju seksualno posjedovati jer time utvrđuje svoju poziciju 
apsolutne moći. U toj se sceni potpuno otkrivaju sve razine njegove igre koja na simboličkoj razini uzrokuje smrt glavne junakinje (Fraisl 164).

Nakon njegova odbijanja Agnes ponovo opsjedaju (auto)destruktivne misli i emocije. Paradoksalno joj upravo otac u ruke daje oružje koje mijenja njezinu poziciju iz žrtve u poziciju moći i priliku da svom zlostavljaču oduzme pravo da upravlja njezinim životom (Polt-Heinzl 214). Iako se činilo da junakinja ne uspijeva zauzeti kritički stav prema bilo kojemu segmentu manipulacije kojoj je bila izložena unutar tzv. eksperimenta, pištolj joj na simboličkoj i stvarnosnoj razini omogućava repozicioniranje na društvenoj ljestvici. Ocoubojstvom do tada submisivna kći demonstrira novu moć i pokazuje apsurd psihoanalitičke teorije (Box 33). Na taj način igra koju je psihijatar do tada vodio, završava njegovim ubojstvom, a ne samoubojstvom pacijentice. Bez obzira na to što je svjesna činjenice da će završiti u zatvoru ili u umobolnici, junakinja u posljednjoj rečenici u noveli prvi put pokazuje nadu u budućnost: „Tiho, uvjereno, gotovo kličući, ponavlja Agnes: 'Moj život počinje!'“ (Hartwig, Das Verbrechen 61).

\section{Vještica (Die Hexe)}

Radnja novele Vještica smještena je u doba 30-godišnjeg rata (1618. - 1648.), vjersko-političkog sukoba vodećih europskih sila koji se u literaturi naziva ratom svih ratova (Burkhardt 15). U noveli se čitatelji konfrontiraju s mnogim scenama radikalnog nasilja, psihičkih i fizičkih patoloških stanja, kao i prizorima silovanja i smrti. Glavna junakinja je nahoče odgojeno među katoličkim redovnicima koji su se zavjetovali na šutnju pa kasno upoznaje govor i svoj identitet legitimira pomoću tijela i tjelesnosti (Fraisl 197). Kako, uslijed okolnosti u kojima je odrasla, nije imala priliku razviti svoj intelekt, ona se formira u intuitivno biće i zadržava posebnu vezu s prirodom. Kad njezina intuicija dođe u kontakt s govorom i spoznajom svijeta, junakinja počinje demonstrirati natprirodne sposobnosti. Ona se svojim vještinama koristi da bi pomogla ljudima, međutim, klerikalno-militarističke strukture guše bilo kakav model ženske autonomije pa kažnjavaju djevojčicu čiji karakter nije u skladu s njihovim normama i vrijednostima. U društvu 17. stoljeća nema prostora za čudesno nahoče; institucionalni oblici moći koju predstavljaju crkveni i svjetovni autoriteti prvo uzrokuju smrt njezinih roditelja, potom ju odgajaju u izolaciji, siluju i na kraju zapale na lomači. Iako Rune više pripada neobičnim nego psihopatološkim ženskim likovima, njezino ponašanje izlazi iz granica normalnog, dok neki drugi likovi u noveli pokazuju sadizam i neuroze tipične za psihičke bolesnike. Usto se u noveli javlja 
i motiv zastrašujuće zarazne bolesti, odnosno kuge koja izobličuje fizionomiju ljudi i pretvara ih u neljudska bića. Međutim, Hartwig pokazuje da bolest poput kuge neće samo uništiti ljudska tijela, njezin utjecaj ima dalekosežne posljedice i reflektira se kao smrt humanosti, rađanje mržnje i nasilja te kulminira u linču nevinog bića. Upravo će strah od bolesti, praznovjerje i mizoginija potaknuti ubojstvo jedne djevojčice i pokazati da patologija nije samo obilježje pojedinca, nego i društva u cjelini.

Glavna junakinja na svijet dolazi u bizarnim okolnostima u kojima se sjedinjuju i izjednačavaju život i smrt (Grubišić Pulišelić, Witches 44). Njezina majka rađa dok među svjetinom promatra javno pogubljenje svoga muža, a potom iznenada umire. Ubojstvo, javna egzekucija, okrutnost, smrt, razbojstvo i rađanje novog života stapaju se u jedinstvenu sliku koja odražava duboku patologiju klerikalno-militarističkog društva. Novorođenče otkriva grobar, a njegova trudna žena stoji na čelu čitavog niza likova koji u noveli pokazuje psihopatološke crte ličnosti. Ona euforično nagovara muža na ubojstvo očito uživajući u projekciji patnje tek rođene djevojčice, na gušenje pod zemljom ili prerezani grkljan. Grobar ipak odustaje od plana da dijete živo zakopa pa bizaran splet događaja dovodi do toga da ga pronalaze redovnici jednog katoličkog reda. Oni taj događaj percipiraju kao božji znak, a kako žensko tijelo u njihovu sustavu vrijednosti simbolizira napast i iskušenja, djevojčicu krste imenom Rune koje asocira na predkršćansko doba i znači tajna (Polt-Heinzl 219). Krštenje djevojčice unutar zidina katoličkog samostana predstavlja čin prihvaćanja u kršćansku zajednicu, dok ime iz doba poganstva pokazuje da ona za njih predstavlja paradigmatskog drugog (Fraisl 195). Sukladno imenu koje su joj nadjenuli, glavna će junakinja cijeli svoj život predstavljati misterij za svoju okolinu, od nepoznatog porijekla do nadnaravnih sposobnosti zbog kojih će na kraju biti proglašena vješticom i spaljena na lomači.

Odrastajući među redovnicima koje obvezuje zavjet šutnje, djevojčica nije u prilici upoznati govor pa misli i osjećaje izražava neverbalnim znakovima, odnosno svojim tijelom (Fraisl 197). Slučajni susret s govorom za nju predstavlja važnu prekretnicu u njezinu do tada bezidentitetskom stanju, dok njezina reakcija demonstrira ponašanje koje se iz perspektive socijalno prihvatljivog može okarakterizirati kao patološko. Šokirana otkrićem da postoji verbalni način komunikacije, junakinja u agoniji mahnito udara rukama oko sebe, plače, ispušta očajničke krikove i tuli poput životinje. Rune instinktivno osjeća da joj je uskraćeno ono što predstavlja izlaz iz njezine besvjesne egzistencije i to verba- 
lizira na jedini joj dostupan način, svojim tijelom (Fraisl 201). Da bi ju utješili, redovnici pripreme slavlje u njezinu čast: „Šest dana redovnici su pripremali slavlje, ali sedmoga su mirovali i Rune uveli u salu" (Hartwig, Die Hexe 213). Jasna je autoričina alegorija na božje stvaranje svijeta, dok će zločin kojim će događaj završiti otkriti ljudsku psihopatologiju u snažnom kontrastu prema idealiziranom božjem svijetu (Grubišić Pulišelić, Witches 47). Kao intuitivno biće Rune svoje emocije iskazuje govorom tijela: glasno se smije, plješće dlanovima i pleše gola. Taj prizor u redovnicima budi potisnutu seksualnu energiju pa padaju u trans i zalijevaju ju crnim vinom koje asocira na krv i simbolizira zločin silovanja: „Tada se životinja bacila na nju gušeći dlakavim šakama njezin vrisak sve dok se nije hropćući ugušila pod teretom njegove volje [...]" (Hartwig, Die Hexe 217). Zaštitnici se transformiraju u zlostavljače, nemilosrdno ju udaraju šakama, bijesno grizu i siluju sve dok ne izgubi svijest. Može se zaključiti da se u toj sceni muška seksualna energija spaja se s instinktom smrti, odnosno pojednostavljeno, po Freudu redovnicima upravljaju thanatos i eros koji združeni dovode do silovanja (Lohmann 47-56). U sljedećoj fazi svog života Rune postaje ratni plijen, odnosno vlasništvo zapovjednika protestantske vojske. Između njih razvija se neka vrsta odnosa na relaciji otac - kći: on postaje potpuno opsjednut djevojčicom, poučava ju značenju riječi, štiti od opasnosti i obasipa poklonima. Rune osim govora upoznaje i stvarni svijet iz njegovih priča, ali realnost koju joj on prenosi temelji se na njegovu iskustvu rata, nasilja i smrti (Polt-Heinzl 222). Zbog fascinacije zlatnim novčićima junakinja započinje igrati bizarnu igru u kojoj se prvi put pokazuju njezine čudesne sposobnosti. Njezina strast prema zlatu tjera ju na devijantne oblike ponašanja pa počinje potkradati vojnike po šatorima i svojim tijelom plaćati im odštetu. Njezin odnos prema vlastitoj seksualnosti pokazuje se kao duboko patološki obojan: junakinja se prepušta spolnom činu s vojnicima jednako ravnodušna prema užitku, kao i prema boli: „Ošamućena i rastvorena u grozničavoj omami mirisa, nije osjećala ni zadovoljstvo ni bol, željna napuniti ruke stranim blagom“ (Hartwig, Die Hexe 224). Nezasitna glad koju osjeća za zlatom može se tumačiti kao psihopatološko stanje koje nastaje kao posljedica nerealizirane potrebe za ljubavi (Grubišić Pulišelić, Witches 51). Logorom se počinju širiti priče o njezinim nadnaravnim sposobnostima: „Kako ona pronalazi zlato? Poznaje li ona naše tajne? Zna li više od drugih ljudi? Ovo je opasno“ (Hartwig, Die Hexe 225). Kad presuše izvori vode junakinja na isti način otkriva podzemne izvore dok ju vojnici prate u deliriju žeđi: „Kako je mogla pronaći izvore? Poznaje li i tajne prirode? Zna li više od drugih ljudi? To nije dobro!“ (Hartwig, Die Hexe 225) Njezine čudesne vještine 
počinju izazivati strah kod ljudi, ali Rune nastavlja sa svojim otkrićima. Za njih pronalazi bačve s vinom u podrumu spaljenog grada, a na kraju i zlatne kovanice. Svoju radost zbog otkrića pokazuje neverbalnim načinom izražavanja, odnosno svojim tijelom kojim još uvijek percipira svijet oko sebe (Polt-Heinzl 220). Prizor golog ženskog tijela pokrivenog zlatnicima istovremeno izaziva fascinaciju i iskonski strah kod vojnika. Runin ples u zlatu doživljavaju kao nešto još ljepše, čudesnije, ali i okrutnije od rata pa zaključuju da to mora biti djelo samoga vraga (Grubišić Pulišelić, Witches 52).

Kad u logoru zavladaju glad i kuga, djevojčicu počinju percipirati kao vješticu krivu za svo zlo koje im se događa. Rune počinje imati zastrašujuće vizije: „Krv, osjećam krv, puno, previše krvi. [...] Prokletstvo bjesni zemljom, primam ga u svom srcu, zapalilo se, u njemu postaje plamen smrti. Teško meni i prokletstvu. Gorim!“ (Hartwig, Die Hexe 233) Junakinja luta između mrtvih tijela i promatra "lica s maskom smrti“ (Hartwig, Die Hexe 233), a nadolazeća tragedija daje se naslutiti u stvaranju atmosfere jeze. U noveli se redaju strašni opisi unakaženih, od kuge trulećih tijela i mozgova koji uokolo štrcaju. Glavna junakinja do zore luta među mrtvim i poluživim, od bolesti deformiranim tijelima i izobličenim licima. Bolest i njezine vizije krvi i smrti sjedinjuju se u prijeteću atmosferu koja kulminira još jednim strašnim zločinom. Runino tijelo postaje objekt u rukama razularene svjetine te se na simboličkoj razini ponavlja scena grupnog silovanja. Žensko se tijelo u vatri lomače pretvara u ugljen, crni prah koji simbolizira duboku patologiju jednog mizoginog društva.

\section{Zapisi jedne ružne žene (Aufzeichnungen einer Häßlichen)}

Novela Zapisi jedne ružne žene napisana je u obliku ispovijesti iz perspektive pripovjedača u prvom licu - bezimene bolničarke koja prepričava recentne događaje iz svog života (Fraisl 182). Pripovijedanje je prekinuto analepsama koje razotkrivaju nova značenja i tumačenja njezina psihičkog stanja. Tekstom u potpunosti dominira motiv bolesti: radnja se najvećim dijelom odvija u prostoru bolnice u kojoj protagonisti, bolničarka i liječnik u kojeg se zaljubljuje, rade i stanuju. Glavna junakinja doživljava transformaciju ličnosti od psihički zdrave do psihički nestabilne/bolesne osobe, a potom uspijeva nanovo uspostaviti psihičku ravnotežu i pronaći svoj mir kao bolničarka u ustanovi za duševne bolesnike. 
Identitet glavne junakinje konstruiran je na dvije različite razine: ona je bolničarka koja se potpuno realizira u svom zanimanju/funkciji i žena koja se zbog svoje fizičke ružnoće/neprivlačnosti ne uspijeva samoostvariti u emocionalnom i seksualnom smislu. Novela započinje jednostavnom izjavnom rečenicom: „Ja sam ružna“ (Hartwig, Zapisi jedne ružne žene 131). Autoportret junakinje u funkciji je literarizacije stvarnosti u kojoj ružnoća nije tek stvar subjektivne percepcije, već dominantni faktor njezina života. Pripovjedačica vrlo precizno definira svoje mjesto u društvu te ističe da je svjesno odabrala zanimanje bolničarke kao žene bez seksualnog identiteta: „Zanimanje bolničarke nisam izabrala nenamjerno. Obećala sam sebi gorku radost bezuvjetne predanosti“ (Hartwig, Zapisi jedne ružne žene 132). Za bolničarku se može konstatirati da predstavlja ideal ženskog karaktera toga doba jer pruža iluziju osobno motiviranog kontakta s bolesnim čovjekom (Bischoff 13).

Životnu prekretnicu za nju označava udaja jedne ružne prijateljice daktilografkinje, žene s tipičnim modernim zanimanjem (Frevert 25) koja usprkos svojoj fizičkoj neprivlačnosti uspijeva osvojiti svoga šefa. Pripovjedačica doživljava određeni šok i traumu; tim za nju neobjašnjivim događajem završava razdoblje njezine pomirenosti sa životom žene koja se samoostvaruje isključivo u svom zanimanju, odnosno u žrtvovanju za bolesnike. Taj brak za junakinju predstavlja dokaz da i fizički neprivlačna žena može ostvariti emocionalnu i seksualnu vezu s muškarcem te uzrokuje početak njezine transformacije iz racionalne / psihički zdrave u iracionalnu / psihički bolesnu osobu. Umjesto željenim brakom, njezin pokušaj preobrazbe završava psihopatološkim stanjem, a potom nekom vrstom (samo)izolacije.

Junakinja počinje maštati o romantičnoj ljubavi i izgrađuje čitav jedan paralelni svijet fantazija koji uskoro preuzima dominaciju nad stvarnim životom: „Željela sam biti među ljudima, sudjelovati u njihovim radostima i zluradostima, pripadati zajednici srca“ (Hartwig, Zapisi jedne ružne žene 132). Ona sve teže razlučuje granicu između zbilje i imaginacije pa se kao posljedica takve unutarnje konstelacije pojavljuju različiti psihopatološki fenomeni. Počinje umišljati da nepoznati muškarci pokazuju interes za nju, uhodi ljubavne parove i razvija mržnju prema lijepim ženama. Junakinja povlači oštru granicu između svog identiteta prije i poslije preobrazbe: dok je prije predstavljala paradigmatski primjer tradicionalne žene koja se samoostvarivala u žrtvovanju za druge, u fazi transformacije pokušava izgraditi društveni život po uzoru na ideal moderne žene (Koch 16-19). Nevješta u socijalnoj komunikaciji i odnosima, svoje 
maštarije pokušava ostvariti na razne karikaturalne načine: „Ali tada ni to više nije bilo dovoljno, željela sam privući njihovu pažnju, [...] hotimičnim ispuštanjem opernih naočala na pod ili ophođenjem s konobarom povišenim tonom, [...], namjernim sudaranjem na vratima, samo da bih na sebe privukla poglede muškaraca [...]“ (Hartwig, Zapisi jedne ružne žene 132-33). Junakinja neumorno pokušava ostvariti socijalne kontakte s osobama suprotnog spola pa posjećuje kazalište, kavane i koncerte, ali njezino ponašanje ne rezultira ostvarenjem fantazija, već samo potencira razvoj duševne bolesti.

Iako se trudi infiltrirati u noćni život grada, ona se zaljubljuje u muškarca koji pripada bolničkom miljeu, čime se motivi ljubavi i seksualnosti dovode $\mathrm{u}$ usku vezu s motivom bolesti. Zaljubljenost u jednog liječnika pretvara se u opsjednutost te se kod nje razvija erotomanska deluzija. U svakodnevnoj komunikaciji vidi znakove naklonosti, umišlja da on koketira s njom i da joj uzvraća osjećaje (Rinke 34). Junakinja na simboličkoj razini kreće na (neuspješni) put identitetske preobrazbe - od ružne i neprivlačne bolničarke u neku vrstu femme fatale. U tu svrhu opsesivno kupuje luksuzne predmete, svilene haljine, otmjeno donje rublje i šminku (Rinke 36) sukladno činjenici da je moda predstavljala važan segment života tzv. nove žene toga razdoblja (Koch 16-19). Nekontrolirano trošenje teško zarađene životne ušteđevine simbolizira njezinu psihičku nestabilnost, odnosno nemoć racionalnog rasuđivanja i djelovanja: „Kupovala sam i kupovala sve što mi se činilo korisnim, neselektivno i neobuzdano. Jednostavno nisam mogla prestati, trnci osjećaja užitka tjerali su me od trgovine do trgovine sve dok nije bio protraćen i posljednji novčić“" (Hartwig, Zapisi jedne ružne žene 137). Potpuno nekompetentna u socijalnom ophođenju, odnosima i komunikaciji s muškarcima, ona u prostoru bolnice nosi svilenu haljinu vjerujući da će tako zavesti objekt svoje zaljubljenosti/opsesije. Kontrast između luksuzne odjeće koju nosi ispod bolničke kute i ambijenta bolnice kao mjesta kojim dominiraju motivi bolesti i smrti zrcali apsurd njezina pokušaja transformacije. Pokušaji zavođenja na radnom mjestu usto rezultiraju tragikomičnim situacijama i posljedično kod nje razvijaju nove psihičke poremećaje (Rinke 33-34).

Zauzimajući distancu prema događajima iz prošlosti, ona pokajnički priznaje da je prije nego što se zaljubila intenzivno posjećivala mjesta noćnog života $u$ potrazi za nekom vrstom seksualnog uzbuđenja. Već u toj fazi očiti su znakovi psihopatologije koji se projiciraju u voajerskim sklonostima (Polt-Heinzl 216), ali i (auto)agresivnim ispadima. U vjerojatno najšokantnijoj sceni u noveli junakinja se prisjeća događaja u jednom noćnom klubu gdje je skrivena u mračnom 
kutu promatrala muška i ženska tijela u plesu. Njezina seksualna frustracija dovodi ju do napada bijesa pa iz svog skrovišta izlazi na plesni podij da bi jednu nepoznatu lijepu ženu udarila šakom posred lica (Schmid-Bortenschlager 90). Iako ni sama nije sigurna je li se taj prizor zaista dogodio ili je bio samo plod njezine mašte, događaj ilustrira razvoj određenih psihopatoloških fenomena kod junakinje, ali i intenzivno ispreplitanje stvarnosti i fantazije. I drugi događaji kojih se prisjeća demonstriraju duševnu neuravnoteženost, seksualnu frustraciju i potrebu da se izmišljenim situacijama kompenzira nezadovoljavajuća stvarnost. Nakon što se zaljubljuje, odlučuje odreći se svojih fantazija, ali ih zapravo samo preusmjerava: „Ali tim ekscesima moje mašte, shvatila sam, moralo je za ljubav dr. B.-a doći kraj. To velikodušno odricanje, tu žrtvu dugovala sam svojoj ljubavi“ (Hartwig, Zapisi jedne ružne žene 145).

Junakinja svoje deluzije prenosi na drugu razinu i fokus prebacuje s nepoznatih ljudi na točno određeni objekt. Započinje proces u kojemu se potpuno usredotočuje na pokušaj pretvaranja deluzije u stvarnost pa u svakodnevnim situacijama u bolnici pokušava isprovocirati interes muškarca u kojeg se zaljubila. Na liječnički pregled tako dolazi našminkana i odjevena u večernju haljinu: „Odjenula sam - ne, nije bilo smiješno, ne, tužno, samo je bilo tužno - odjenula sam večernju haljinu, jedinu večernju haljinu koju sam posjedovala. Nisam mislila na to da je vedro popodne, samo sam mislila da svoju najsvečaniju haljinu nosiš u najsvečanijoj prigodi svog života" (Hartwig, Zapisi jedne ružne žene 147). Njezin osjećaj frustracije raste pa se u sljedećem kontaktu s voljenim muškarcem potpuno psihički slama: „Ružna sam, o Bože, zašto sam samo tako ružna. Vi ne znate koliko sam ružna. To je moja tajna. To je moja bolest. To je moj život. [...] Zašto sam uopće na svijetu? Zašto uopće živim?"“ (Hartwig, Zapisi jedne ružne žene 152) Kad junakinja saznaje da je dr. B. zaručen, percipira to kao izdaju i doživljava živčani slom. U tom ispadu verbalizira sve svoje frustracije, vrijeđa ga i napada, a potom mu duševno rastrojeno ljubi ruke i klečeći pred njim priznaje da je zaljubljena u njega. Iako u početku obazrivo odbija njezino udvaranje, dr. B. sve teže podnosi pritisak koji kulminira njezinim zahtjevom da joj podari dijete pa ju naziva histeričnom, odnosno bolesnom (Polt-Heinzl 216). Poražena u svim pokušajima uspostavljanja bliskosti s objektom svoje ljubavi/ opsesije, junakinja ga počinje potajno uhoditi. Samoostvarenje nalazi u novom modelu ponašanja: ulazi u njegovu sobu i potajno pere, pegla i sprema njegovu odjeću. Njegova reakcija kod nje izaziva šok koji predstavlja prekretnicu u njezinu psihopatološkom stanju. Samoj sebi pokajnički priznaje da je živjela u 
deluziji: „Živjela sam drugu, fantastičnu, sladostrasnu, dvosmislenu stvarnost srca, [...]" (Hartwig, Zapisi jedne ružne žene 198). Povratak u stvarnost prvo rezultira suicidalnim mislima, a potom potpunim prekidom s dotadašnjim načinom života. Stabilizaciju svog psihičkog stanja pronalazi u ustanovi za duševne bolesnike, okružena ljudima koji žive izvan realnosti pa ih društvene norme ne dotiču: „Strahovala sam od spoznaje da me od njih dijeli samo pedalj svijesti i mukotrpna stega. Dan za danom bojala sam se da bih jednom rečenicom mogla prijeći u njihov kamp. Danas ih volim. Oni su dobrodušni i djetinjasti (Hartwig, Zapisi jedne ružne žene 202). Neostvarena ljubav prema muškarcu i potisnuta seksualnost transformiraju se u osjećaj naklonosti prema psihičkim bolesnicima (Schmid-Bortenschlager 85).

Takvim razvojem događaja u noveli Hartwig pomiče granice između onog što se po društvenim normama percipira kao normalno i onoga što se osuđuje kao psihopatološko (Fraisl 191). Junakinja svoju normalnost uspostavlja upravo služeći onima čija je bolest deklarirana i potkrijepljena medicinskom dokumentacijom pa se može zaključiti da se upravo zahvaljujući tom apsurdu otvara prostor kritičkog preispitivanja društvenih odnosa i vrijednosti.

\section{Fantastični paragraf (Der phantastische Paragraph)}

Iako se motiv bolesti provlači kroz sve tekstove objavljene u zbirci Ekstaze, u noveli Fantastični paragraf motiv (psiho)patologije zauzima središnje mjesto. Glavna je junakinja siromašna studentica medicine po imenu Sabine Seltsam koja boluje od tuberkuloze i umišlja da je zatrudnjela s mjesecom. Ona je opisana kao višestruko stigmatizirana žena jer je fizički neprivlačna, bolesna i siromašna (Polt-Heinzl 218). Cijela njezina tjeskobna egzistencija koncentrirana je oko pojma bolesti: pokazuje se da patologija zapravo posjeduje njezino krhko tijelo (Fraisl 176) i određuje njezinu sadašnjost i budućnost. U noveli se problematizira pitanje vlasništva nad ženskim tijelom; država sa svojim represivnim aparatom diktira odnos žene prema vlastitoj tjelesnosti, prisiljava ju na neželjeno majčinstvo čak i onda kad njezino bolesno tijelo nije sposobno za to. Sudac koji na kraju novele, u ime države koju predstavlja, ženu proglašava krivom za abortus samo je posljednji u nizu reprezentanata maskuline moći koji upravljaju njezinim tijelom. Međutim, Hartwig otkriva da postoji još šokantnija razina kontrole i manipulacije koja prodire u najintimnije i najskrivenije područje ženskih potisnutih želja i fantazija (Polt-Heinzl 212). Zato je za državu i njezine predstavnike irelevantno je li se zločin prema tijelu zaista dogodio ili je posto- 
jala samo namjera žene da svojim postupcima krši pisane zakone i/ili nepisana pravila patrijarhalno-autokratske kulture.

Bolesno tijelo nije samo izvor frustracija za junakinju (Fraisl 176); ono definira njezin autsajderski položaj na imaginarnoj socijalnoj ljestvici. Sabine je zbog svoje patologije osuđena na usamljenost, tjeskobu i osjećaj besperspektivnosti, neslobode i zakinutosti za životnu radost. Doživljeni seksualni čin u davnoj prošlosti pokazuje se kao središnje mjesto njezina života (Fraisl 173) pa joj jedinu radost predstavljaju trenuci u kojima evocira proživljene trenutke strasti i impresivnu/uzbudljivu snagu muškog tijela. Kao njezina posebna karakteristika naglašena je bizarna fascinacija mjesecom; Sabine kod pune mjesečine otvara prozore da bi mjesec mogao prodrijeti u njezinu sobu. Nebesko tijelo čarobno preobražava svijet oko nje, njezina skromna soba u potkrovlju dobiva srebrene tapete, pohabani prekrivač pretvara se u brokat, a njezini se „iscrpljeni udovi opuštaju u požudnom pijanstvu usamljene požude“ (Hartwig, Der phantastische Paragraph 63). Tada doživljava neobično (izvan)tjelesno iskustvo; osjeća kako mjesečeve zrake prodiru u svaku poru i potpuno preuzimaju dominaciju nad njezinom svijesti: „Omamio je čudesnim nasiljem trezvenost njezinih misli i volje, potaknuo poremećenu želju [...] njezinog od tuberkuloze oboljelog tijela“ (Hartwig, Der phantastische Paragraph 63). Ovisnost o mjesecu i moć koju ima nad njezinim bolesnim tijelom prikazani su kao psihopatološki fenomen: „To joj je uvijek dolazilo iznenada, poput bolesti, zagrijavalo njezinu krhku, sterilnu maštu poput groznice [...]" (Hartwig, Der phantastische Paragraph 63). U tim trenucima prisjeća se „svečane tajne svog života“ (Hartwig, Der phantastische Paragraph 64), odnosno ljubavnika iz prošlosti, kontura njegova tijela i crta njegova lica. U kontekstu Freudovih teorija, taj ritual doživljavanja seksualnog zadovoljenja u snovima može se tumačiti kao odraz potisnutog libida (Lohmann 21).

Jedne noći junakinja doživljava posebno intenzivne trenutke: mjesec ulazi u njezinu sobu, poprima obrise muškarca iz njezine prošlosti i vodi ljubav s njom. Njezino tijelo reagira izljevom potisnutih emocija, a njezin um prima poruku da će roditi dijete. Sljedećeg jutra ni sama nije sigurna u to je li spolni odnos bio samo mjesečarenje koje je rezultirao intenzivnim osjećajem užitka (Fraisl 176-77) ili se događaj zaista dogodio. Kad je njezina gazdarica uvjerava u to da su cijele noći iz njezine sobe dopirali zvukovi strastvene ljubavne igre, junakinja povjeruje u čudo (Polt-Heinzl 219). Tajanstveni se muškarac u njezinoj mašti transformira u hibrid nastao križanjem mjeseca i ljubavnika iz njezine prošlosti, dok izostanak mjesečnice shvaća kao dokaz trudnoće. Iako je to u početku 
raduje, $s$ vremenom osvještava činjenicu da svaka trudnoća završava rađanjem djeteta, činom za koji njezino od tuberkuloze bolesno tijelo nije sposobno (Fraisl 173). Dok u prvom dijelu novele junakinja traži medicinsku pomoć za prekid svoje umišljene trudnoće, $\mathrm{u}$ drugom dijelu počinju njezine nevolje sa zakonom zbog optužbe za namjerno izazivanje pobačaja. U prvom dijelu koji je u fokusu ove analize, dominira motiv bolesti, dok se u drugom dijelu radnja orijentira prema motivu pravosuđa i (ne)pravde.

Sabine počinje osjećati fizičke simptome umišljene trudnoće što u njoj izaziva paniku: „Samo sam htjela biti trudna. Stvarnost je opasna. Ipak se ne osjećam kao majka, samo se osjećam kao ljubavnica“" (Hartwig, Der phantastische Paragraph 71). Strah od majčinstva za koje njezino tijelo nije spremno i za koje nema materijalne uvjete (Fraisl 174) tjera ju na (auto)destruktivno ponašanje. U neuspješnim pokušajima izazivanja prekida trudnoće, junakinja se samoozljeđuje i doživljava napade panike. Svoj problem u početku pokušava riješiti institucionalno (Fraisl 174) pa prvo odlazi svojoj socijalnoj skrbnici. Uzaludno ju pokušava uvjeriti u to da nije zdravstveno i financijski sposobna imati dijete. Skrbnica pokazuje birokratsku nezainteresiranost i nedostatak empatije, a na Sabininu tvrdnju da je otac djeteta vilenjak, hladno konstatira da joj je potrebna pomoć psihijatra: „Trebali biste potražiti psihijatra“ (Hartwig, Der phantastische Paragraph 76). Junakinja se prvi put susreće s dijagnozom psihičke bolesti i očajnički pokušava dokazati da je njezin problem organske prirode pa kao dokaz podastire maramicu uprljanu krvlju: „Ali ja sam bolesna. Imam tuberkulozu“" (Hartwig, Der phantastische Paragraph 76). Hartwig nesumnjivo kritizira sustav socijalne skrbi toga doba, kao i lošu liječničku skrb za društvene marginalce (Polt-Heinzl 218). Junakinja si kao siromašna studentica ne može priuštiti privatnog liječnika pa odlazi u ordinaciju za socijalne slučajeve. U sljedećim scenama potpuno dominira motiv patologije: u maloj, zagušljivoj čekaonici sluša kašalj tuberkuloznih pacijenata i udiše teški zrak ispunjen „svim zamislivim bolestima“" (Hartwig, Der phantastische Paragraph 80). Liječnik se ponaša po istom uzorku kao socijalna skrbnica, a junakinja se mora konfrontirati ne samo s njegovim odbijanjem nego i s cijelim bešćutnim društvenim sustavom koji on reprezentira. Sabine ga ne uspijeva uvjeriti u to da čin rađanja ne predstavlja samo smrtnu presudu za njezino bolesno tijelo, već i za novorođenče: „I kako ćete ga zaštititi od tuberkuloze koju će isisati iz mojih grudi?" (Hartwig, Der phantastische Paragraph 83). Zaštićen autoritetom svoje funkcije, liječnik zauzima moralno superioran stav i optužuje junakinju da simulira psihičku i 
organsku bolest da bi izbjegla majčinstvo (Fraisl 178). Nakon institucionalne, Sabine zatraži izvaninstitucionalnu pomoć, ali si ne može priuštiti ilegalni pobačaj. Junakinja shvaća da je država/sustav tjeraju da „rodi vlastitu smrt“ i da za nju kao siromašnu neudanu ženu ne postoji mjesto spasa: „Nevoljko je, poput klice opasne bolesti, nosila dijete u sebi, osjećala kako joj poput vampira izvlači krv i život iz vena" (Hartwig, Der phantastische Paragraph 89). Dijete koje nosi počinje percipirati kao bolest koja iz nje isisava život. Postaje autodestruktivna, izgladnjuje i iscrpljuje svoje tijelo u nadi da će tako izazvati prekid trudnoće. $\mathrm{Na}$ kraju iskoristi svoje medicinsko znanje da bi zabranjenom supstancom izazvala jako krvarenje: „[...] osjećala je ljepljivu tekućinu, ćutila je miris krvi i srušila se. Sad je osjećala kako joj krv teče niz bedra, sve više i više, sve opasnije“ (Hartwig, Der phantastische Paragraph 91). Hartwig detaljno opisuje procese kroz koje prolazi izmučeno žensko tijelo, gubitak krvi i bol od kojih gubi svijest. Dok u bolnici lebdi između života i smrti, Sabine osluškuje zvukove i identificira mirise koji asociraju na patološka stanja i smrt: „Groznica ju je zgrabila za grlo i gušila njezin dah [...]" (Hartwig, Der phantastische Paragraph 96).

Nakon borbe za goli život za junakinju započinje borba za istinu koju polako osvještava. Na sudu pokušava dokazati da je njezina trudnoća bila samo plod mašte i da se pobačaj za koji je optužena nije ni dogodio (Fraisl 175). Međutim, patrijarhalno-autoritarni sustav pokazat će još jednom svoje mizogino lice reprezentiran likom suca koji ju proglašava krivom. Paradoksalno će ju on, kao posljednji institucionalni predstavnik u nizu, proglasiti psihički zdravom da bi nad njom mogao demonstrirati moć koju predstavlja.

\section{Zaključak: (psiho)patologija kao sudbina žene}

Hartwig literarizira živote žena kojima (psiho)patologija postaje sudbina zbog njihovih fizičkih i/ili psihičkih karakteristika. Kod Agnes iz novele Zločin psihički poremećaj razvija se kao posljedica eksperimenta koji njezin otac provodi dok u procesu dokazivanja Freudove teorije psihoanalize prekoračuje etičke granice. Junakinja se ne može obraniti od njegova destruktivnog utjecaja na njezinu psihu niti može očekivati pomoć iz vanjskog svijeta jer je on taj koji reprezentira institucionalnu i društvenu moć. Kako joj njezin odgoj nije omogućio razvoj samopouzdanja, samosvijesti i autonomije, ona kao submisivna žena nema izgleda u borbi protiv patrijarhalno-autokratskih struktura. Pobuna protiv nametnutog znanstvenog i obiteljskog autoriteta stoga se može realizirati samo izvan granica sustava, odnosno u prostoru kriminaliteta. Iako novela za- 
vršava prije nego što junakinju sustignu posljedice njezina čina, jasno je da će ona, oslobodivši se moći svog zlostavljača, postati žrtva institucionalne moći i da će ju počinjeni zločin zauvijek obilježiti kao društvenu otpadnicu.

Rune iz novele Vještica postaje žrtva klerikalno-militarističkog društva 17. stoljeća koje formalno više ne egzistira u doba nastanka djela, ali uvid u kontekst otkriva da se u odnosu prema ženama promijenilo mnogo manje nego što se to na prvi pogled čini. Strahovi, predrasude, tabui i stereotipi jednako obilježavaju i društvo 20. stoljeća; mizoginija i lov na vještice samo su poprimili neki novi oblik. Nepoznavanje govora, tradicije, običaja i etičkih normi junakinju formiraju u intuitivno biće koje svoju povezanost s prirodom pokazuje nalazeći izvore vode ili predosjećajući bolest i smrt. Iako svojim čudesnim moćima želi pomoći ljudima, oni ju kažnjavaju smrću jer se ženskoj individui ne može tolerirati odstupanje od poznatog/dopuštenog/prihvatljivog ponašanja.

Bezimena junakinja iz novele Zapisi jedne ružne žene u početku je racionalna bolničarka kojoj društvene norme zbog njezinih fizičkih karakteristika oduzimaju pravo na emocionalni život. Kad se pokuša izboriti za pravo na ljubav i seksualnost, doživljava traumatična iskustva koja ju tjeraju u psihopatološka stanja. I ona od početka nema nikakve šanse suprotstaviti se sustavu ili ga mijenjati; tek kad prihvati činjenicu da promijeniti može samo vlastita očekivanja od života, nalazi svoj duševni mir izopćena iz zajednice kojoj je godinama požrtvovno služila.

Sabine iz novele Fantastični paragraf od svih ženskih likova u Ekstazama najradikalnije utjelovljuje (psiho)patološki ženski lik. Njezino organski bolesno tijelo ne može se nositi s društvenim očekivanjima, pravilima i normama te ona podsvjesno bira svijet fantazija kao bijeg od surove i nesretne stvarnosti. Kao bolesnoj ženi uskraćeno joj je pravo na seksualnost, ljubav i majčinstvo pa sve to kompenzira u svojim mjesečarskim avanturama. Ali društvena struktura koja ju odbacuje kao ženu, kažnjava čak i njezine snove i nasilno ulazi u prostor njezine najdublje intime da bi ju ponizila i kaznila. I kod nje se (psiho)patološko stanje očituje kao sudbina koja ju vodi prema socijalnoj diskvalifikaciji, oduzimanju slobode i statusu društvenog izopćenika.

Hartwig u svim tim novelama preispituje različite (psiho)patološke fenomene kod svojih ženskih junakinja i otkriva institucionalne i izvaninstitucionalne mehanizme koji uspostavljaju ili brišu granicu između normalnog/prihvatljivog i bolesnog/neprihvatljivog ponašanja. U 17. stoljeću društveni mehanizmi žene 
proglašavaju vješticama i spaljuju na lomačama, dok je u 20. stoljeću njihov instrumentarij sofisticiraniji pa se služe zakonima i dijagnozama da bi ih smjestili u zatvore i umobolnice.

\section{Literatura}

Bader-Zaar, Birgitta. „Die politische Partizipation der bürgerlich-liberalen Frauenbewegung in Österreich 1918-1934." Österreichische Zeitschrift für Geschichtswissenschaften, sv. 26, br. 2, 2015, str. 93-117.

Bischoff, Claudia. Frauen in der Krankenpflege. Zur Entwicklung von Frauenrolle und Frauenberufstätigkeit im 19. und 20. Jahrhundert. Campus, 1992.

Box, Marijke. „Es ist, als ob du mich schlügst. Das tragische Spiel um Scham, Schuld und Gewalt in Mela Hartwigs Das Verbrechen." IZGOnZeit.Onlinezeitschrift des Interdisziplinären Zentrums für Geschlechterforschung, br. 6, 2017, str. 23-38.

Burkhardt, Johannes. Der Dreißigjährige Krieg 1618-1648. Edition Suhrkamp, 1992.

Catani, Stephanie. Das fiktive Geschlecht. Weiblichkeit in anthropologischen Entwürfen und literarischen Texten zwischen 1885 und 1925. Königshausen \& Neumann, 2005.

Fähnders, Walter. „Über zwei Romane, die 1933 nicht erscheinen durften. Mela Hartwigs Bin ich ein überflüssiger Mensch? und Ruth Landshoff-Yorcks Roman einer Tänzerin." Regionaler Kulturraum und intellektuelle Kommunikation vom Humanismus bis ins Zeitalter des Interne, Axel E. Walter (ur.), Rodopi, 2004, str. 161-90.

Fast, Evelyn. Das Frauenbild der 20er Jahre - Literarische Positionen von Irmgard Keun, Marieluise Fleißer und Mela Hartwig. GRIN, 2006.

Fraisl, Bettina. Körper und Text. (De-)Konstruktionen von Weiblichkeit und Leiblichkeit bei Mela Hartwig. Passagen, 2002.

Grubišić Pulišelić, Eldi. „Witches and Unaccomplished Mothers: Female Outcasts in Mela Hartwig's The Witch." Folia Linguistica et Litteraria, sv. 34, br. 1, 2021, 41-57.

---. „Žena je jedno ništa Mele Hartwig: Feminizam u književnom narativu postimperijalnog naslijeđa“. Književna smotra, sv. 188, br. 2, 2018, str. 95-103.

Hall, Murray G.. Der Paul Zsolnay Verlag. Von der Gründung bis zur Rückkehr aus dem Exil. Max Niemeyer-Verlag, 1994.

Hartwig, Mela. „Das Verbrechen“. Das Verbrechen. Novellen und Erzählungen, Droschl, 2004, str. 19-61.

---. „Der phantastische Paragraph“. Das Verbrechen. Novellen und Erzählungen, Droschl, 2004, str. 63-129.

---. „Aufzeichnungen einer Häßlichen“. Das Verbrechen. Novellen und Erzählungen, Droschl, 2004, str. 131-202.

---. „Die Hexe“. Das Verbrechen. Novellen und Erzählungen, Droschl, 2004, str. 203-35.

Koch, Christiane. „Sachlich, sportlich, sinnlich. Frauenkleidung in den zwanziger Jahren.“ Neue Frauen. Die zwanziger Jahre, uredili Kristine von Soden i Maruta Schmidt, Elefanten Press, 1988, str. 16-19. 
Lohmann, Hans-Martin. Sigmund Freud zur Einführung. Junius, 2002.

Matijašević, Željka. „Freud: neuroze, psihoze i shvaćanje analize“. Zarez http://www.zarez. hr/clanci/freud-neuroze-psihoze-i-shvacanje-analize, pristupljeno 9. travnja 2021.

Polt-Heinzl, Evelyne. „Mela Hartwigs Fallgeschichten. Korrekturen zum Thema Hysterie.“ Literatur und Kultur im Österreich der Zwanziger Jahre. Vorschläge zu einem transdisziplinären Epochenprofil, Primus-Heinz Kucher (ur.), Aisthesis, 2007, str. 211-26.

Rinke, Stefanie. „Zur Politik toxischer und nicht-toxischer Ekstasen.“ Kritische Berichte, sv. 38, br. 4, 2010, str. 29-38.

Schmid-Bortenschlager, Sigrid. „Der zerbrochene Spiegel. Weibliche Kritik der Psychoanalyse in Mela Hartwigs Novellen." Modern Austrian Literature, sv. 12, br. 3-4, 1979, str. 77-95.

Sykora, Katharina. „Die Neue Frau. Ein Alltagsmythos der Zwanziger Jahre.“ Die Neue Frau. Herausforderung für die Bildmedien der Zwanziger Jahre, uredili Katharina Sykora et al., Jonas, 1993, str. 9-24.

Ute Frevert. „Kunstseidener Glanz: Weibliche Angestellte“. Neue Frauen. Die zwanziger Jahre, uredili Kristine von Soden i Maruta Schmidt, Elefanten Press, 1988, str. 25-31.

Wagner, Nike. Geist und Geschlecht. Karl Kraus und die Erotik der Wiener Moderne. Suhrkamp, 1982. 


\title{
(PSYCHO-)PATHOLOGISCHE PHÄNOMENE IN MELA HARTWIGS EKSTASEN
}

\author{
Zusammenfassung
}

EIdi GRUBIŠIĆ PULIŠELIĆ

Philosophische Fakultät der Univesität Split, Kroatien

Poljička cesta 35, 21000 Split

eldi@ffst.hr

Im Mittelpunkt dieses Beitrags stehen (psycho-)pathologische Phänomene, die weibliche Heldinnen aus vier Novellen der österreichischen Schriftstellerin Mela Hartwig (Das Verbrechen, Der Phantastische Paragraph, Aufzeichnungen einer Häßlichen und Die Hexe) verbinden. Das Bindeglied zwischen ihnen ist die Positionierung der Hauptfiguren in Bezug auf gesellschaftliche Werte, Normen und Erwartungen, d. h. ihr Außenseiterstatus. In den Novellen Das Verbrechen, Aufzeichnungen einer Häßlichen und Der Phantastische Paragraph müssen sich die Heldinnen mit verschiedenen Paradigmen der frauenfeindlichen österreichischen Kultur des frühen 20. Jahrhunderts auseinandersetzen. In der Novelle Die Hexe, die im 17. Jahrhundert spielt, ist die gesellschaftliche Konstellation etwas anders, sodass die Heldin mit veränderten Machtkonzepten konfrontiert wird. Hartwig untersucht verschiedene (psycho-)pathologische Phänomene, die bei ihren weiblichen Figuren auftreten, und entdeckt (außer-)institutionelle Mechanismen, die die Grenze zwischen normalem/akzeptablem und krankem/unakzeptablem Verhalten festlegen oder aufheben. Ihre Heldinnen reagieren auf Unterdrückung mit Selbstmordversuchen, promiskuitivem Verhalten, Wahnvorstellungen, Rückzug in eine parallele Fantasiewelt, Konstruktion übernatürlicher Erfahrungen und sogar mit Mord. Psychopathologische Phänomene, die zu einem integralen Bestandteil ihrer Identität werden und ihren körperlichen und geistigen Ausdruck begleiten, projizieren ihren verzweifelten Ruf nach Hilfe. Ihr Kampf endet in einer Niederlage, weil sie als einsame Individuen nicht über die Macht der institutionellen Autoritäten triumphieren können. In ihren literarischen Texten zeigt die Autorin die ängstliche, depressive und sogar psychotische Realität der Frauen. Die schockierenden und/oder bizarren Situationen, die sie literarisch verarbeitet, erlauben es den Lesern, die Atmosphäre einer Epoche zu rekonstruieren, die paradoxerweise in den schriftlichen Quellen und im kollektiven Gedächtnis unter dem Begriff der Goldenen Zwanziger bekannt ist.

Schlüsselwörter: Mela Hartwig, psychopathologische Phänomene, Misogynie, institutionelle Macht, Frauen 


\title{
(PSYCHO)PATHOLOGICAL PHENOMENA IN MELA HARTWIG'S EKSTASEN
}

\author{
Abstract \\ Eldi GRUBIŠIĆ PULIŠELIĆ \\ Faculty of Philosphy, University of Split, Croatia \\ Poljička cesta 35, 21000 Split \\ eldi@ffst.hr
}

The focus of this paper is on (psycho)pathological phenomena that connect female heroines from four literary works by the Austrian writer Mela Hartwig. The link between them is the position of protagonists in relation to social values, standards and expectations, i.e. their outsider status. In the novellas The Crime, The Records of an Ugly Woman, and The Fantastical Paragraph, the heroines must confront different paradigms of the misogynist Austrian culture of the early twentieth century. In The Witch, a novella set in the seventeenth century, the social constellation is somewhat different, hence the heroine is confronted with modified concepts of power. Hartwig examines various (psycho)pathological phenomena that occur in her female characters and discovers (extra)institutional mechanisms that establish or erase the boundary between normal/acceptable and sick/unacceptable behavior. Her heroines react to oppression by attempting suicide, promiscuous behavior, delusions, retreating into a parallel world of fantasies, constructing supernatural experiences, and even by murder. Psychopathological phenomena that become an integral part of their identity and accompany their physical and mental expression, project their desperate call for help. Their struggle ends in defeat because as lonely individuals, they cannot triumph over the power embodied by institutional authorities. In her texts, the author shows the anxious, depressive, and even psychotic reality of women, the shocking and/or bizarre situations she literarizes allow readers to reconstruct the atmosphere of an era that is, paradoxically, in written sources and collective memory known under the phrase The Golden Twenties.

Keywords: Mela Hartwig, psychopathological phenomena, misogyny, institutional power, women 